\title{
Disco polo jako zasób kontrhegemoniczny wobec metamorficznych praktyk wizerunkowo-estetycznych na przykładzie wybranych narracji medialnych
}

\author{
Disco Polo as Counter-Hegemonic Resource \\ Against Metamorphic Image and Aesthetic Practices \\ on the Example of Selected Media Narrations
}

- Powiedzieć czy nie?

- Coś ważnego?

- Bardzo ważnego, bez tego w Ameryce przegracie...

- To wal...

- Ludzie, zróbcie coś z waszymi polskimi mordami.

Szczęśliwego Nowego Jorku, 1997

O czym mówimy, kiedy mówimy o disco polo?

Disco polo od czasów transformacji ustrojowej było wciągnięte w swoistą wojnę kulturową pomiędzy „elitami” a „ludem”, a dokładniej mówiąc, pomiędzy wyobrażeniami wyobrażonych elit na temat wyobrażeń wyobrażonego ludu. W tym sensie disco polo jest czymś więcej niż tylko gatunkiem muzycznym. Ujmowane w perspektywie klasowej jest etykietą służącą do stygmatyzowania i ośmieszania ludzi mniej zamożnych ze wsi i małych miasteczek. To oni bowiem w wyobrażeniach elit dysponują mniejszym czy po prostu innym kapitałem kulturowym, w związku z czym nie pasują do modernizującej się Polski ze względu na swój jakoby „ludowy” gust estetyczny kojarzony z kiczem, a ogólniej, pewnym stylem życia wyrażanym poprzez tę muzykę. Jej słuchacze muszą zostać poddani edukacji 
muzycznej, w tym przemianie wizerunkowo-estetycznej oraz przemianie mentalnej (określam je mianem praktyki metamorficznej), aby dołączyć do wyobrażonej klasy średniej reprezentującej odpowiednie wartości tej klasy przejawiające się m.in. w guście muzycznym, czy szerzej kulturalnym, budującym obraz pożądanego, w domyśle liberalnego obyczajowo i neoliberalnego ekonomicznie stylu życia.

Na wstępie należy podkreślić dwie kwestie. Po pierwsze, owa przylepiana etykieta:

wytwarza złudzenie, że coś jest jakieś, to znaczy, że ta cecha jest stałą właściwością nazywanego zjawiska [...] i że formuła werbalna wyrażająca to przekonanie jest z pewnością prawdziwa, czyli wyraża twierdzenie o świecie, którego nie sposób zanegować. Nie dość zatem, że etykietuje się świat, to również mitologizuje rzeczywistość, do której wypowiedź-formuła się odnosi. Mit jest bowiem „językiem imion własnych", te zaś utożsamiają nazwę z denotatem, tak że spostrzega się ją jako jedyną możliwą. Mit jest przy tym (zgodnie ze znanym określeniem), systemem semiotycznym żerującym na słowie. Upraszczając opisy zdarzeń, operujące przede wszystkim obrazem, a dodatkowo zależne od języka potocznego, różne odmiany komunikacji masowej (kino, telewizja, reklama, prasa wielkonakładowa), z „natury” i rodzaju znaków używanych konwencji stylistycznych są szczególnie podatne na tworzenie przekazów „mitopodobnych”.

Moim zdaniem, ten mitopodobny zabieg esencjalizujący disco polo (jest kiczem obiektywnym) ma swoje klasowe uwarunkowanie, gdyż to w rękach klasy dominującej, w tym jej intelektualnych elit, „operuje się obrazem” o charakterze ideologicznym, który narzuca się klasie podporządkowanej, w tym słuchaczom disco polo. Przyjęcie tego obrazu ma na celu wywołanie w nich poczucia wstydu, który przełoży się na chęć porzucenia przywiązania do tego gatunku i wejście na jedynie słuszną drogę rozwoju gustu, w tym przyjęcia określanych i pożądanych wartości przez klasę dominującą. „Łatwość” disco polo musi zostać porzucona na rzecz „trudności” sztuki wysokiej, co można postrzegać jako klasowy element inicjacji² (jak np. praktyki utrzymywania mieszkania w czystości) ${ }^{3}$.

Po drugie, taka metamorficzna praktyka czasu transformacji nie jest niczym nowym, by wspomnieć chociażby książkę Elizabeth Dunn pt.

I Z. Kloch, Odmiany dyskursu. Semiotyka życia publicznego w Polscepo Ig8g roku, Wrocław 2006, s. I46.

2 M. Napiórkowski, Trudność muzyki poważnej jako wspótczesna próba inicjacyjna, „Sztuka i Filozofia” 2012, nr 40, s. II8-133.

3 M. Rydlewski, Scenariusze kultury upokarzania. Studium z antropologiimediów, Wrocław 2019, s. I23-13I. 
Prywatyzując Polskę, w której amerykańska antropolożka ukazuje m.in. przemiany socjalistycznego kierownika w kapitalistycznego menadżera. Kierownik uosabiał wszystko to, co prenowoczesne/socjalistyczne, czyli klientelizm i łapówkarstwo, którego celem było osiąganie indywidualnych korzyści. Z kolei menadżer uosabia wszystko to, co pożądane, a więc nowoczesne/kapitalistyczne. To model autonomicznego i racjonalnego w swych decyzjach profesjonalisty, który pracuje na korzyść firmy, a nie na swoją własną. Metamorfoza kierownika w menadżera (lub zastąpienie jednego przez drugiego) jest zmianą stylu życia; dopiero ten element odzwierciedla istotę tej przemiany. Menadżer kierujący się wartościami elastyczności, otwartości, innowacyjności musi je niejako uwewnętrznić, one muszą stać się jego wartościami, a raczej odwrotnie: to on, w sensie psychologiczno-osobowościowym, musi stać się takim jak te wartości, aby osiągnąć sukces w firmie: będziesz menadżerem nie dlatego, że to a to potrafisz, ale dlatego, że taki a taki jesteś. Kluczowy jest fakt, iż te nowe wartości muszą zostać oddelegowane na przedmioty, całą sferę tego, co materialne i widzialne. Nie może zatem dziwić, że fundamentalnym pojęciem staje się pojęcie wizerunku; człowiek staje się obrazem, zostaje w niego przemieniony. Jak trafnie zauważa E. Dunn, wizerunek, czyli „zewnętrzne ja” odzwierciedla zmiany (rzeczywiste lub potencjalne) $w$,wewnętrznym ja”. Zbudowany $z$ odpowiedniego ubioru, pasji, jedzenia, gestów, gadżetów wizerunek menadżerów komunikowat, $\mathrm{iz}$ - po pierwsze - nabyli odpowiedniej wiedzy dotyczącej zarządzania oraz - po drugie - sąjuż gotowi do pracy na rzecz firmy ${ }^{4}$. W przypadku disco polo i jego słuchaczy należało ich wyedukować muzycznie i dostosować do zachodnich kanonów gustu muzycznego nastawionego na muzykę pop i jej „konsumpcję”, z tego względu należało usunąć wszelkie znaki „ludowości”, „swojskości”, „lokalności”, „polskości”, słowem - „discopolowości”.

Na przełomie Xx i XXI w. wydawało się, że disco polo odejdzie w zapomnienie, pozostając jedynie wstydliwym epizodem polskiej rzeczywistości lat 90. XX w. Disco polo nie umarło, jak wieścił grzebiący je kiedyś dziennikarz Robert Leszczyński, lecz istnieje dzisiaj w postaci zarówno naiwno-realistycznej (Weekend, Zenek), jak i ironiczno-żernej (Sławomir), i co więcej, cieszy się dużą popularnością. Metamorficzna praktyka polegająca na przerobieniu gustu tzw. klasy ludowej przez elity nie powiodła się, w tym sensie disco polo i jego słuchacze okazali się mocnym zasobem kontrhegemonicznym wobec budowanej różnymi sposobami i narracjami hegemonii neoliberalnej. Dodatkowo, podobnie jak w latach 90., uwikłali się czy

4 E. Dunn, Prywatyzujac Polskę: o bobofrutach, wielkim biznesie i restrukturyzacji pracy, przeł. P. Sadura, Warszawa 2017, s. 89-95. Zob. także: A. Szarecki, Kapitalizm somatyczny: ciato i wtadza w kulturze korporacyjnej, Warszawa 2017. 
zostali uwikłani w wojnę polityczną pomiędzy partią reprezentującą interesy elit i tych, którzy skorzystali na przemianach transformacji ustrojowej, a partią, która reprezentuje interesy tych, którzy „nie załapali się” na stosunkowo dostatnie życie w objęciach konsumpcji ${ }^{5}$. W tym sensie disco polo stało się polityczne, jak rower, mięso, polowania, beret, tęcza, rurki, a jego obecność jest kulturalnym odwetem na intelektualnych elitach, które pogardzały tą muzyką. Dzisiaj to ona jest pokazywana w telewizji publicznej. Film o Zenku Martyniuku (a nie na przykład o Oldze Tokarczuk) i jego obecność w telewizji publicznej świadczy, iż rządząca partia, jako że media publiczne znajdują się w jej rękach, skutecznie realizuje gust estetyczny swoich wyborców dokładnie tak, jak poprzednia władza realizowała gust swoich, współpracując i zapraszając do sponsorowanych przez siebie wydarzeń takich, a nie innych artystów.

Wykorzystując teorię hegemonii, a dokładniej mówiąc, relację pomiędzy hegemonią a kulturą opisaną przez badaczy ze szkoły z Birmingham postrzegających kulturę jako nośnik narzucania ideologii ${ }^{6}$, postaram się pokazać, jak stygmatyzuje się ten gatunek muzyki i jego słuchaczy na kilku wybranych przykładach narracji medialnych. Owa stygmatyzacja ma na celu wywołanie w słuchaczach disco polo poczucia wstydu ze swojego niskiego gustu muzycznego, przyznanie przed samym sobą, że jest się kimś gorszym od tych, którzy ten gust mają elitarny. Zarządzanie poprzez wstyd ma z kolei na celu dopasowanie ich do pożądanego przez elity wyobrażenia o klasie średniej wyznającej wartości tej klasy ukształtowane w dużej mierze przez ideologię neoliberalną. Ujawnia się w tej praktyce metamorficznego dopasowania wiele naleciałości historycznych, m.in. wstyd z chłopskiego pochodzenia biorących udział w ocenie tej muzyki oraz jej słuchaczy. Wymazanie discopolowego gustu, stylu i wizerunku jest w dużej mierze tożsame z wyegzorcyzowaniem z siebie „wieśniaka” jako elementu niepasującego do nowoczesnych wyobrażeń i ponowoczesnego stylu życia7.

Moja główna teza jest zatem następująca: disco polo, nawet jeśli rzeczywiście słuchane głównie na wsi ${ }^{8}$, jest etykietą przylepianą tym, którzy są

5 M. Borys, Polski bajer. Disco polo i lata 9o., Warszawa 2019, s. 98-100.

6 Kultura i hegemonia. Antologia tekstów szkoty z Birmingham, red. M. Wróblewski, Toruń 2012, s. 13-45; M. Wróblewski, Wierni jako zasób kontrhegemoniczny: spór o krzyż w kontekście teorii hegemonii, „Kultura Popularna” 2014, nr I, s. I4-35; M. Wróblewski, Hegemonia i wtadza. Filozofia polityczna Antonio Gramsciego i jej wspótczesne kontynuacje, Toruń 2016. Michałowi Wróblewskiemu, mojemu toruńskiemu Koledze, zawdzięczam intelektualną sympatię do szkoły z Birmingham.

7 M. Rydlewski, Nowi-starzy obcy w realnym kapitalizmie. Mieszkańcy polskiej wsi jako ofiary swojego stylu życia (na przyktadzie wybranych obrazów medialnych), [w:] Retro sentyment, retro moda, retro nadzieje, red. M. Czapiga-Klag, M. Rydlewski, Wrocław 2019, s. I13-1 45.

8 M. Borys, dz. cyt., s. I04-105, 252-256. 
zasobem opornym wobec procesu budowania hegemonii kulturowej przez elity reprezentujące (świadomie lub nie) ideologię neoliberalną, gdyż jej autentyczni słuchacze (ci, którzy tę muzykę po prostu lubią) reprezentują wartości konserwatywne, choć trudne do precyzyjnego zdefiniowania, takie jak: rodzina, polskość, tradycja, sentymentalizm, wspólnotowość, lokalność, zakorzenienie, katolicyzm, na które nakłada się wyobrażona „ludowość" gustu muzycznego te wartości reprezentująca?. Ten zasób kontrhegemoniczny względem nowoczesnej, czy nawet ponowoczesnej wizji społeczeństwa, sprawia, że stają oni w gardle wszelkim projektom modernizującym „bycia takim jak na Zachodzie”, albowiem są zbyt swojscy. Słowem, część elit intelektualnych nie może się pogodzić z faktem, że są ludzie po prostu tej muzyki słuchający i którzy nie chcą być kimś z wyobrażeń elit. Wygląda to tak, jakby część elit nie mgła zupełnie zrozumieć, że ludzie z różnych grup społecznych i klas słuchają różnej muzyki, co pokazuje, że owa część elit nie akceptuje relatywnego statusu gustów estetycznych oraz nie jest tolerancyjna względem odmienności, choć nosi tolerancję na swoich ideologicznych sztandarach. Pokazuje to tym samym, że jest to tolerancja deklarowana, a nie faktycznie obowiązująca, gdyż polegająca na tolerowaniu tylko tych gustów i postaw, które mieszą się w neoliberalnym imaginarium. W takim ujęciu pojęcie kiczu, o czym będzie jeszcze mowa, służy jako dystynkcja do odgradzania się „nas” od „nich”, „elit” od „ludu”, w wersji mocniejszej - „pana” od „chama”.

Podsumowując, mówiąc o disco polo, mówimy o podziałach społecznych w polskim społeczeństwie i antagonizowaniu tego społeczeństwa. Mówimy także o głównych emocjach - wstydzie, pogardzie, upokorzeniu i gniewie ${ }^{\mathrm{IO}}$ - i odniesieniach przedmiotowych tych emocji, poprzez które jesteśmy zarządzani w toczonych wojnach kulturowych sprawnie zastępujących dyskusję o nierównościach społecznych zrodzonych w okresie transformacji. Jak zauważa Monika Borys: „Spór wokół muzyki popularnej w różnych jego przejawach, od ironicznej gali w Sali Kongresowej w 1992 roku po dzisiejsze upolitycznione perypetie disco polo, choć kłopotliwy, jest jedną z najżywszych i najbarwniejszych dyskusji o podziałach polskiego

9 Tzw. „muzyka ludowa” to tylko jeden z elementów genezy disco polo, i choć wcale nie najważniejszy, to jednak przez samych muzyków chętnie podkreślany, co widoczne jest w filmie Bara, Bara. Szerzej na ten temat patrz: Z. Woźniak, Fenomen disco polo i jego miejsce w polskiej kulturze masowej lat dziewięćdziesiątych, „Etnografia Polska” 1998, t. 42, s. 187-203; K. Dabert, Krótka historia disco polo, "Zeszyty Etnologii Wrocławskiej” 2012, nr I, s. 57-70; W. Filar, Fenomen muzyki disco polo w kontekście polskiej kultury popularnej lat go., „Kultura Popularna” 20I4, nr I, s. IO2-II9, M. Małanicz-Przybylska, Disco polo from the Podhale region: the cultural Power game, „Ethnologia Polona” 2018, vol. 39, s. 91-107.

Io M. Rydlewski, Scenariusze...; T.S. Markiewka, Gniew, Wołowiec 2020. 
społeczeństwa. Polska kwestia smaku kipi tutaj najmocniej" ${ }^{\text {II }}$. Słuchacz disco polo to po prostu uosobienie ciemnogrodu, o którym trafnie pisał Tomasz Markiewka, pokazując różne stereotypowe wyobrażenia o grupach społecznych zamieszkujących Polskę:

Ciemnogród to pogardliwe określenie ludzi, którzy mają opinię zacofanych, głupich, niebezpiecznych. [...] Mniej więcej tak najbardziej zawzięci wyborcy Platformy Obywatelskiej przedstawiają sobie wyborców PiS. Ciemnogrodzianin jest konserwatywny, bogobojny i zawsze gotowy spełniać polecenia księży. Łatwo nim manipulować. Nie docierają do niego racjonalne argumenty, kieruje się przesądami. Boi się świata, bo też i słabo go zna, jest przesiąknięty ksenofobią. To również człowiek po prostu niekulturalny. [...] Jest on raczej mieszkańcem wsi niż miasta. Wykształcenie - rozumie się samo przez się - ma podstawowe, góra zawodowe. Dzieci kilkoro. Nie zarabia zbyt wiele, o ile w ogóle pracuje. Nie uczestniczy w życiu kulturalnym, bo słuchanie disco polo i oglądanie głupkowatych seriali to nie kultura ${ }^{12}$.

\section{Krytyka disco polo w mainstreamowym dyskursie medialnym (wybrane przykłady)}

Przyglądając się historii disco polo, należy odnotować, iż okres największej popularności tego gatunku muzycznego przypadł na lata 90. XXw., przy czym w pierwszej połowie miał się chyba lepiej niż w drugiej. Do roku 2012, kiedy zawrotną karierę zrobiła piosenka Weekendu, o disco polo stosunkowo niewiele się mówiło (zresztą ten fenomen zasługuje na porządną monografię naukową). M. Borys trafnie zauważyła, iż piosenka Ona tańczy dla mnie stała się ,symbolem nowej fali disco polo”. Ze względu na fakt, iż jest to utwór całkiem dobry z miłym dla oka teledyskiem, osiągnęła ogromny sukces (pierwsza polska piosenka, która trafiła na listę Ioo najpopularniejszych piosenek na YouTube, a po czterech latach miała roo mln odsłon) ${ }^{r_{3}}$. Warto jednak podkreślić, że w chwili pojawienia się tej piosenki, a dobrze pamiętam ten czas, nie była ona powszechnie kojarzona $\mathrm{z}$ disco polo, choć miała wiele cech tego gatunku, ile raczej $\mathrm{z}$ muzyką pop, co pokazuje, że disco polo w nowej formule, w nowych estetycznych dekoracjach może się odnaleźć i być słuchane zarówno na weselu, jak i dyskotece.

II M. Borys, dz. cyt., s. 256.

I2 T.S. Markiewka, dz. cyt., s. I52-153.

I3 M. Borys, dz. cyt., s. 237. 
Ażeby zobaczyć argumentacyjną , strukturę długiego trwania”, jaka była stosowana przez elity intelektualne w latach 90. XXw. i jest dzisiaj powielana, przyjrzę się kilku wybranym narracjom medialnym na jej temat oraz poddam je krytyce.

M. Borys w Polskim bajerze przypomina dyskusję dotyczącą disco polo, jaka miała miejsce na łamach „Tygodnika Powszechnego” w 1996 r. Była ona próbą nakreślenia granic pomiędzy sacrum sztuki wysokiej a profanum kultury popularnej oraz wyznaczeniem miejsca w okresie potransformacyjnym inteligencji jako grupie społecznej. M. Borys ma rację, stwierdzając, iż Tadeusz Sobolewski, który ową dyskusję wywołał, nie zwraca uwagi na podziały warunkujące pozycje w hierarchii społecznej, a więc i dostęp do kultury ${ }^{14}$.

Sobolewskiemu - pisze warszawska kulturoznawczyni - nie tyle chodzi o krytykę konkretnych cech disco polo - traktuje je powierzchownie, nie zagłębiając się w muzyczne niuanse - ile raczej o wyznaczenie jasnych granic estetycznych i jednocześnie społecznych; chce uświęcić swoją pozycję, a wszystko co jest ,disco polo", uznać za profanum. W takiej wizji kultury linie podziału są ostre. Sobolewski pisze o tym wprost: „stoimy za blisko siebie”s.

Refleksja T. Sobolewskiego uwidacznia kilka istotnych kwestii, które będą się niezmiennie pojawiały aż do dzisiejszej dyskusji o disco polo. Pierwsza to kwestia klasowości i absolutyzacji własnego gustu estetycznego jako znaku rozpoznawczego przynależności do klasy wyższej, druga - to brak najmniejszej choćby próby zrozumienia fenomenu disco polo jako interesującego zjawiska kulturowego. Część intelektualistów tamtego czasu wypowiadająca się o disco polo uważała, iż nie trzeba poznawczo wnikać w ten fenomen, żeby móc się o nim wypowiadać, gdyż to co gorsze nie zasługuje na antropologiczną czy socjologiczną refleksję. Disco polo jakie jest, każdy widzi. To właściwie zadziwiające, że fenomen disco polo nie doczekał się pogłębionego namysłu, a refleksja nad nim istnieje, poza kilkoma artykułami naukowymi, w formie dziennikarsko-publicystycznej. Ten brak szerszego spojrzenia osadzonego w kontekście społeczno-historycznym lat 90. XX w. sprawia, że zamiast mówić o rzeczywistości disco polo, mówi się o swoich wyobrażeniach o disco polo i to w sposób tak mocno przeniknięty oceną i wartościowaniem, że wręcz uniemożliwiający jej zrozumienie. Określeniem, które ma załatwić całą sprawę, jest kicz, jakim jest disco polo. Nie ma gorszej obelgi niż kicz, który jest granicą klasowości, społecznej

\footnotetext{
I4 Tamże, s. 76.

Is Tamże.
} 
dystynkcji (do wątku tego powrócę). Nie zajmujmy się tą szmirą, chciałoby się powiedzieć, albowiem "piętno społecznego wstydu, którym obarczona jest discopolowa kultura, ma obezwładniającą moc - do tego stopnia, że nie pozwalało to na dokładniejsze przyjrzenie się chodnikowej twórczości i kryjącym się w niej fantazjom. Uznanie tego nurtu w całości za nieinteresujący kicz spowodowało, że ogromny obszar polskiej wyobraźni nadal pozostaje nieodkrytym lądem" ${ }^{16}$.

Jednym z najciekawszych, z mojego punktu widzenia, głosów dotyczących disco polo była wypowiedź R. Leszczyńskiego odnotowującego z radością, zupełnie błędnie - jak się okaże - śmierć disco polo. W odróżnieniu od T. Sobolewskiego, R. Leszczyński ma pojęcie o samej muzyce, co jednak nie zmienia faktu, iż jest do niej wrogo nastawiony. W artykule w „Gazecie Wyborczej” pt. Pogrzeb disco polo z lubością odnotowuje fakt, iż: „Od kilku miesięcy nakłady kaset z muzyką disco polo spadają na teb, na szyję! Disco polo przegrywa z muzyką pop i na powrót staje się prowincjonalnym folklorem" ${ }^{17}$.

Można powiedzieć [pisze dalej], że disco polo wraca do domu. Oczywiście ta muzyka nie zniknie z dnia na dzień, ale spadek zainteresowania publiczności wymusi taką samą reakcję w mediach. Disco polo będzie się marginalizować, aż zajmie miejsce, jakie zajmują jej odpowiedniki w innych krajach. Całe to zjawisko, które napędziło takiego stracha elitom kulturalnym, okazało się krótkotrwałą eksplozją. Wybuch był proporcjonalny do siły, z jaką ta muzyka była przez lata thamszona przez „oficjalny obieg”. Kiedy przyszedł wolny rynek w mediach i fonografii, publiczność upomniała się o „swoją muzykę”. Z czasem jednak spowszechniała i nawet najwytrwalsi fani zauważyli jego monotonię. Sięgnęli po więcej. Wyedukowali się. To najwspanialszy finał, jaki można sobie wyobrazićr ${ }^{18}$.

W jego ujęciu, muzyka disco polo to prowincjonalna muzyka niewyedukowanych słuchaczy, która przegrała ze znacznie lepszą, „o piekło lepszą”, jak mówi R. Leszczyński, muzyką pop. Pomijając fakt, że tym o „piekło lepszym” zespołem miała być, według dziennikarza muzycznego, np. Mafia (wystarczy na własną rękę zapoznać się z tekstami kilku ich piosenek, by zobaczyć w nich banał, a nawet grafomanię), należy podkreślić pewną wymowną sprzeczność w jego wypowiedzi. Otóż wprost przyznaje, z jednej strony,

I6 M. Borys, dz. cyt., s. 9.

I7 R. Leszczyński, Pogrzeb disco polo, „Gazeta Wyborcza”, 6 II 1997, s. I2. Nawiasem mówiąc, w cyfrowym Archiwum Gazety Wyborczej tytuł tego tekstu opatrzony jest znakiem zapytania, którego w oryginalnym wydaniu nie ma, gdyż jest to tekst z tezą, a nie postawieniem pytania.

I8 R. Leszczyński, dz. cyt., s. I2. 
że ta muzyka była „latami tłamszona” przez „oficjalny obieg”, z drugiej zaś strony „wolny rynek” spowodował, że disco polo umiera, bo publiczność sama wybiera, czego chce słuchać. Ta sprzeczność jest znakomitym przykładem pewnego z ducha neoliberalnego zakłamania elit intelektualnych, w tym szczególnie dziennikarzy muzycznych jako funkcjonariuszy systemu medialnego będącego w rękach klasy uprzywilejowanej. Media miały na celu zbudowanie hegemonii kulturowej poprzez narzucenie ludziom z klasy podporządkowanej swojego własnego gustu, w tym ideologii za tym gustem stojącej. Jak ma się „tłamszenie” do „wolnego rynku”, nie sposób pojąć, trudno też uznać za świadomy wybór odpowiedniej muzyki, jeśli ta jest po prostu narzucana. Elity intelektualne, w tym dziennikarze muzyczni pokroju R. Leszczyńskiego, tkwią w zaklętym kręgu swoich wyobrażeń, albowiem najpierw sami medialnie "tłamsili” disco polo, a potem mówią, że to nie oni, lecz wolny rynek, który przecież, jak widać, wolny nie jest. Przemoc uzasadniana jest wolnym rynkiem.

Kwestia wolnego rynku zasługiwałaby w ogóle na osobne omówienie, gdyż na przykładzie dostępu disco polo do mediów głównego nurtu, trudno powiedzieć o wolnym rynku pojmowanym jako regulowanie podaży i popytu. Wolny rynek, tutaj muzyczny, był reglamentowany, a jego ograniczenia były uzasadniane gustem estetycznym, którego wyobrażeń klasy wyższej, w tym dziennikarzy, disco polo nie mogło spełnić. Dlatego w dużej mierze disco polo powstawało i funkcjonowało przez jakiś czas w drugim obiegu, a osoby związane z tą muzyką same zakładały wytwórnie muzyczne, czyli tworzyły infrastrukturę materialną, po której mogła być ona dystrybuowana. Był to przejaw kapitalistycznej przedsiębiorczości, co powinno budzić uznanie, ale tego uznania nie budziło, gdyż nie było zgodne z wyobrażeniami elit intelektualnych.

Kwestię stosunku mediów głównego nurtu do twórców disco polo, i co za tym idzie, szacunku do ich słuchaczy, widać dobrze w filmie pt. Bara, Bara, który został wyprodukowany w 1996 r., oraz m.in. wypowiedzi Tomasza Samborskiego. Ten discopolowy muzyk w tekście pt. Zdtawiliście disco polo trafnie zauważa, że publiczne media są praktycznie zamknięte przed disco polo, choć ma ona stosunkowo dużą publiczność i nie wywołuje złych emocji w ludziach, wręcz przeciwnie. Telewizja promuje pop i rock reprezentowany przez wielkie wytwórnie ${ }^{19}$.

Wszystko to wygląda [twierdzi] jak zmowa w celu zniszczenia tej muzyki, która jest oczywistym zagrożeniem dla interesów wielu ludzi. Wszystko

19 T. Samborski, Zdtawiliście disco polo, „Gazeta Wyborcza”, 6 II 1997, s. I2-13. 
to dziwne i niesprawiedliwe, zważywszy na popularność tego zjawiska i dobre emocje, jakie wywołuje w wielu ludziach. Telewizja jest przecież „publiczna”, a nie „elitarna”。o.

Moim zdaniem ma rację, co przecież wprost stawia pytanie o to, czyje są media. Elity intelektualne uznały, że media są ich, a co przecież powinno być poddane dyskusji, gdyż to nie tylko elity płacą abonament. Wolny rynek to nie tylko dobry argument dla pracowniczego wyzysku, ale i narzucania swojej ideologii pod płaszczykiem wyedukowania się (wszak kto chce uchodzić za niewyedukowanego, w domyśle głupiego, bo wykształcenie jest utożsamione $\mathrm{z}$ mądrością). To nic innego jak bazowanie na wstydzie ze swojego niewyedukowania, a wzbudzanie wstydu to jedna z emocji, którymi neoliberalizm w postaci gustu estetycznego nauczył się znakomicie zarządzać: wstyd, upokorzenie i gniew to, moim zdaniem, najważniejsze emocje naszej rzeczywistości społecznej.

Kwestia ta wymaga komentarza, jeśli ktoś, tak jak R. Leszczyński, stawia siebie w roli arbitra dającego sobie prawo do rozstrzygania o tym, co dobre, a co złe. Abstrahując od mojego krytycznego stosunku do programów telewizyjnych typu talent show, w których dziennikarz był jurorem (są one istotą „kultury upokarzania” ${ }^{21}$ ), to warto przypomnieć jego wypowiedź dla „Newsweeka”, w której powiedział, iż w tych programach nie chodzi o odkrywanie talentów, ale o to, żeby wygrała osoba, na której telewizja zarobi jak najwięcej. Dodał też, że publiczności się tylko wydaje, że wybiera ${ }^{22}$. Dlaczego te słowa przeszły bez echa? Dlaczego intelektualiści nie krytykują tych programów i roli, jaką odgrywają w nich „profesjonaliści”? Czy naprawdę obecność demonizowanego disco polo jest większym zagrożeniem dla kultury, niż kłamstwo i manipulacja marzeniami młodych ludzi o karierze? Najpierw podsuwa im się wyobrażenia o karierze muzycznej realizującej kult widzialności, kapitał kulturowy, jaki mogą nabyć, a następnie nie daje na nią szansy, co przecież powoduje frustrację wynikająca z niespełnienia i realizacji „siebie”. Bądźmy choć trochę sprawiedliwi.

T. Samborski miał rację, pisząc, iż to szczególnie „Gazeta Wyborcza”, jako głos intelektualnej elity, była agresywna w stosunku do disco polo ${ }^{23}$. Ma rację, czego przykłady można znaleźć nie tylko w narracji tej gazety

20 Tamże.

2I M. Rydlewski, Scenariusze...

22 https://weekend.gazeta.pl/weekend/I,I52I21,2039346I,kazde-miasto-ma-swoj-x-factor-moda-na-lokalne-wersje-talent.html [dostęp: I3 czerwca 2020].

23 T. Samborski, dz. cyt. 
w latach 90. XXw., ale także i dzisiaj. Powiela ona dokładnie ten sam typ argumentacji polegający na uznaniu disco polo za kicz.

To kwestia obecna w wypowiedzi, jeszcze do niedawna dziennikarza tej gazety, Grzegorza Sroczyńskiego. W artykule pt. Nie upiększajmy tej szmiry dotyczącym programu Hala odlotów w TVP Kultura, w którym dyskutowano o disco polo, G. Sroczyński stwierdza, że doceniając disco polo dzisiaj, co ma się właśnie manifestować w mówieniu o tym gatunku w programie telewizji publicznej dotyczącym kultury, inteligencja chce odkupić swoją pogardę wobec muzyki chodnikowej. Trudno się nie zgodzić z M. Borys, zdaniem której G. Sroczyński nawoływał do dyskusji o gustach, jednocześnie ją ucinając, i wzywał do zawoalowanej cenzury, twierdząc:

Chciałbym jednak ustalić kilka warunków brzegowych, bez których cała ta nasza zabawa w poważne dziennikarstwo nie ma sensu, nie ma też sensu istnienie kanału TVp Kultura. Otóż disco polo jest złą muzyką, obiektywnie złą, a o gustach jak najbardziej się dyskutuje. Głównie o nich. Oceny artystyczne są oczywiście płynne, a kicz bywa rzeczą względną, bo coś wyklinanego dziś może się jutro okazać arcydziełem - zgoda. Ale nie dotyczy to akurat disco polo, bo tutaj wszystko widać jak na dłoni! [...] Największy przebój Świerzyńskiego, Majteczki w kropeczki, tohohoho, to szmira obiektywna, a nie kwestia gustu, niezrozumienia krytyków czy inteligenckich dąsó $\mathrm{w}^{24}$.

Jak trafnie komentuje jego wypowiedź M. Borys:

Sroczyński postuluje więc, by sądy smaku problematyzować („o gustach się dyskutuje"), ale jednocześnie uznaje, że norma estetyczna jest oczywista, sama się narzuca, a nawet sama się ustala. Dziennikarz wytyka discopolowcom (Świerzyńskiemu i zespołowi Boys) błędy gramatyczne w tekstach, niechlujstwo i ,patentowaną grafomanię". Dyskusja o gustach w interpretacji Sroczyńskiego polega zatem na licytowaniu, czyj gust lepszy i ważniejszy, uciszaniu tych, którzy stoją po stronie „badziewia”, a nie na ujmowaniu umowności samej kwestii smaku czy choćby zastanowienia się nad tym, co brzydkie, według kogo i dla kogo jest jednak ładne ${ }^{25}$.

Ponadto, „odfajkowanie” kwestii disco polo, fenomenu zróżnicowanego i wieloaspektowego, na podstawie jednej piosenki jest mocno problematyczne i niesprawiedliwe, gdyż na tej samej zasadzie można by wskazać

\footnotetext{
24 Cyt. za: M. Borys, dz. cyt., s. 248.
}

25 Tamże, s. 248-249. 
obecność wielu słabych piosenek i zespołów, którym jednak nikt nie zabrania dostępu do telewizji.

I jeszcze kilka nowszych przykładów, których wymowa jest znacznie mocniejsza niż przykładów przywołanych powyżej. Wynika to z faktu, że wzrosła wśród części przedstawicieli elity intelektualnej niechęć czy wręcz agresja względem disco polo jako znaku rozpoznawczego zwolenników Prawa i Sprawiedliwości. Związek disco polo i polityki to kwestia zasygnalizowana przez M. Borys. Obecna jest także w wypowiedzi T. Samborskiego, który ubolewa nad uwikłaniem części środowiska w politykę, na czym straciło ono jako całość, ponieważ zostało zakwalifikowane jako polityczne ${ }^{26}$.

Najlepszym przykładem owej niechęci i agresji jest wypowiedź Hanny Lis, która napisała na swoim Twitterowym koncie, że Jacek Kurski (nazwany przez nią towarzyszem) za pomocą disco polo morduje polską inteligencję tak, jak mordowali ją kiedyś hitlerowcy i sowieci ${ }^{27}$. Jest to porównanie absolutnie przesadzone, czego chyba nie muszę jakoś szerzej komentować. Poza tym, disco polo nie jest gatunkiem muzycznym słuchanym przez akurat tę część naszego społeczeństwa.

Z kolei Zbigniew Mikołejko wpisuje kontrowersję wokół disco polo w napięcie pomiędzy paternalizmem państwa i wolnością jednostki a sztuką wysoką, ujawniając jednocześnie swój stosunek do relatywizmu kulturowego. W wywiadzie z filozofem dziennikarka stwierdza:

Od lat panowała moda na zrównywanie wartości, kultur, dzieł sztuki. I w jakimś sensie byliśmy za tym. Chcieliśmy być poprawni politycznie, czyli oszukiwaliśmy, nie chcieliśmy mówić jak jest. Było modnie uważać, że opowieści przekazywane ustnie w plemionach afrykańskich są równe dziełom Szekspira. Powstały po prostu w innej kulturze, w innym kontekście, w innej tradycji ${ }^{28}$.

Z. Mikołejko skwapliwie podchwytuje tę wypowiedź, dodając: „Ja nie byłem tego zwolennikiem. Jestem orędownikiem silnej demokracji, ale też silnego państwa, które w sposób rozumny tworzy granice dla zbyt szeroko rozumianej wolności. Takiej, która pozwala każdemu na wszystko, co mu się żywnie podoba”. Wypowiedź dziennikarki niezbyt dobrze świadczy o poziomie jej wiedzy, natomiast od profesora filozofii można by wymagać

26 T. Samborski, dz. cyt.

27 https://niezalezna.pl/304237-skandaliczny-wpis-hanny-lis-w-sylwestrowy-wieczor-teraz-sie-tlumaczy-nie-mam-nic-do-disco-polo [dostęp: 13 czerwca 2020].

28 https://kultura.onet.pl/wywiady-i-artykuly/prof-zbigniew-mikolejko-zycie-w-trzewiach-bestii-wywiad/msfl $4 \mathrm{mt}$ [dostęp: I 4 czerwca 2020]. Wszystkie dalsze cytaty pochodzą z tej właśnie rozmowy. 
głębszego namysłu. Każdy student filozofii czy etnologii wie, że relatywizm kulturowy nie jest jakąś współczesną modą, lecz poglądem mającym swoją długą i zawiłą filozoficznie historię, który zmienił myślenie Europejczyków. Pojmowanie politycznej poprawności jako kłamstwa pokazuje kompletne nierozumienie materii, o której się mówi, bo to raczej jakiś obiegowy pogląd na temat politycznej poprawności niż adekwatna wykładnia tego pojęcia. Moim zdaniem, intelektualnie kompromitujące jest także wartościowanie oralności kosztem piśmienności jako dwóch przecież odmiennych form komunikacji i dwóch typów umysłowości (istnieje na ten temat spora literatura). Ponadto klasyfikowanie dzieł Williama Szekspira jako sztuki wysokiej również jest problematyczne, jeśli wziąć pod uwagę historyczny kontekst tamtych czasów.

Sama odpowiedź Z. Mikołejki zmusza do zadania pytania o to, kto i jaką miarą „rozumności” będzie ograniczał tę artystyczną wolność, wyznaczał granice zbyt daleko idącej wolności estetycznej, bo to, że disco polo należy poza te granice usunąć, jest jasne. Powodem tego jest fakt, iż - jak stwierdza dziennikarka - „nasza demokracja dokonała wielu niewłaściwych wyborów”, ustawiając „na szczycie sukcesu finansowego i medialnego” ludzi, „którzy nie tworzą trwałych wartości, nie pracują dla wartości i rzeczy naprawdę istotnych". Pomijając już fakt, czy to faktycznie demokracja jest tutaj jedynym i głównym sprawcą, Z. Mikołejko stwierdza, że:

oglądalność disco polo w telewizji będzie większa niż oglądalność wyrafinowanego teatru lub filmu. Tyle że po piosenkach disco polo nie zostaje w nas nic, one nic w nas nie zmienią, niczego nie nauczą, nie rozproszą naszych lęków. Zostaje tylko - z reguły bezczelne - usprawiedliwienie dla złego gustu, dla schlebiania mu i zwolnienia ludzi z myślenia.

W tej wypowiedzi widać absolutyzację swojego elitarnego gustu, z punktu widzenia którego wszystko inne jest godne pożałowania. Jeśli jest się profesorem filozofii, to można zakładać, że teksty piosenek discopolowych oraz przynależna im estetyka nie spełnią stawianych im z zupełnie innego pułapu wymagań. To oczywiste. Problem w tym, że nie wszyscy są intelektualistami i profesorami filozofii. Owe „nas” jest, po pierwsze, stosunkowo nieliczne, po drugie, dlaczego media miałby ograniczać prawa większości do reprezentacji swojego własnego gustu w postaci danego gatunku muzycznego. Media są publiczne, a nie elitarne, by przywołać wcześniejsze słowa. Z. Mikołejko ma po prostu nadzieję na ręczne regulowanie tego, co powinno być w mediach zgodnie z jego własnym gustem. Ponadto zupełnie nie rozumie on, że muzyka disco polo raczej nie rości sobie prawa 
do bycia sztuką wysoką, ma ona na celu dostarczyć prostej rozrywki i ten cel dobrze realizuje. Nie ma ambicji tworzenia trwałych i istotnych wartości czy zmieniania ludzi. Nie jest po prostu czymś mającym taką funkcję spełniać, gdyż jest to rola sztuki wysokiej. Muzyka disco polo nie jest od rozpraszania lęków (w domyśle lęków egzystencjalnych), bo jest gatunkiem do zabawy, w tym do tańczenia. Widać zatem wyraźnie, że Z. Mikołejko mówi o swoich własnych wyobrażeniach o disco polo, a nie o gatunku muzycznym osadzonym w określonym kontekście społecznym.

Ponadto, jeśli wziąć pod uwagę całość rynku muzycznego, skupiając się na muzyce popularnej, do której należy zakwalifikować gatunek disco polo, to czy inne obecne w jego ramach gatunki spełniają warunki nakładane przez Z. Mikołejkę? Nie, nie spełniają. Czy teksty piosenek popowych rozpraszają nasze lęki ? Czy w ogóle je wywołują? Czy są to dobre teksty dające do myślenia? Nie, nie są. Łatwo wziąć je na warsztat i pokazać, że są banalne czy nawet grafomańskie. Ale te inne gatunki nie interesują Z. Mikołejki, gdyż jego inteligencki obraz świata nakazuje mu skupić się na disco polo.Z. Mikołejko po prostu nie akceptuje różnic gustów pomiędzy ludźmi - „mój gust jest lepszy niż twój”.

Podobnym tropem poszedł chyba, bo to przecież najłatwiejszy wybór, Michał Rusinek, który poinformował w mediach społecznościowych: „Piszę książkę o grafomańskich tekstach polskich piosenek. Może przychodzą Wam do głowy jakieś wybitne dzieła? Zwłaszcza z dziedziny tzw. piosenki estradowej i współczesnej patriotycznej. Będę bardzo wdzięczny za podpowiedzi" ${ }^{29}$. Może warto by najpierw samemu przesłuchać te piosenki i choć spróbować na nie spojrzeć bez z góry założonej tezy?

Warto do tej listy dodać jeszcze dwa przykłady, które obrazują nie tylko niesprawiedliwe podejście do twórców disco polo, ale i zakłamanie samych elit ucieleśnionych $\mathrm{w}$ poglądach reprezentowanych na łamach „Gazety Wyborczej”.

W walentynki 2020 r. gazeta opublikowała artykuł dotyczący filmu Zenek z pytaniem w tytule, jak to się stało, że „człowiek idealnie nijaki podzielił Polskę"3․ Pomijając kwestie podzielenia Polaków, warto podkreślić deprecjonowanie jego sukcesu, gdyż podskórnie tkwi tutaj pytanie o to, jak ktoś bez talentu, z marnym głosem, stał się tak popularny. A przecież można by jego historię pokazać inaczej, np. jako drogę osoby realizującej mit self-mademana, człowieka z prowincji, który dzięki swojej

29 https://krakow.wyborcza.pl/krakow/7,44425,25906805, nietakt-czyli-filolog-czyta-grafomanow.html [dostęp: I2 czerwca 2020].

30 https://wyborcza.pl/7,75410,25697681,zenek-martyniuk-jak-to-sie-stalo-ze-czlowiek-idealnie-nijaki.html [dostęp: I2 czerwca 2020]. 
konsekwencji i uporowi, treningowi i pracy, dostał się na szczyt, osiągnął sukces, powielając schemat innych gwiazd disco polo (np. Shazzy) ${ }^{31}$. Cóż to znaczy, że jest „idealnie nijaki”? A wszyscy inni to osoby wyjątkowe? Zamiast docenić jego trud, pokazać chociażby jako przykład wierności swoim marzeniom, pokazuje się go jako zjawisko w zasadzie kuriozalne, będące zaskoczeniem dla wytrawnych znawców kulturalnych realiów. To zaskoczenie można zinterpretować jako wynik tego, że już nie rozumieją polskiej rzeczywistości społecznej.

Dzień później „Gazeta Wyborcza” informuje, iż w podlaskim Michałowie zostanie utworzona klasa w Liceum Ogólnokształcącym o profilu estradowym $^{32}$. Burmistrz miasta mówi, że głównym celem jest stworzenie młodym ludziom warunków do rozwijania swoich pasji i zamiłowań oraz możliwości zdobycia wykształcenia średniego i zdania matury. Początek tekstu w „Gazecie Wyborczej” brzmi: „W ramach zachęty do nauki w liceum w podlaskim Michałowie ma zostać utworzona pierwsza w Polsce klasa o profilu disco polo. To sposób tutejszych władz na przyciągnięcie młodzieży, która «nie ma sprecyzowanych planów zawodowych»". Nawiasem mówiąc, cytat ten, w perspektywie całości, od razu podskórnie wskazuje, że utworzenie klasy estradowej (estradowej, a nie disco polo) jest jakimś gestem marketingowym mającym na celu przyciągnięcie młodych ludzi ( $\mathrm{i}$ to ludzi o „niesprecyzowanych planach", czyli głupszych, bo ci mądrzy przecież zawsze wiedzą, co chcą robić w życiu) do uczenia się tego, na co akurat jest chwilowa moda (a uczyć trzeba przecież rzeczy poważnych, a nie śpiewania disco polo). Otóżjednak, jeśli wziąć pod uwagę zapotrzebowanie na tę muzykę, uwzględniając chociażby wesela i imprezy okolicznościowe, pomysł powołania klasy o takim profilu jest jak najbardziej racjonalny z ekonomicznego punktu widzenia (znam osobiście osobę, która na tym dobrze zarabia, choć preferuje inną muzykę). Tak działa prawo podaży i popytu. Wszak takiej przedsiębiorczości i zaradności przez lata uczyła właśnie ta gazeta, która sprzyjała neoliberalnym reformom i promuje, np. w osobie Witolda Gadowskiego, ten model do dzisiaj. W czym więc problem? Ano w tym, że nie jest to pożądana klasa fortepianu, czyli profil zgodny z gustem klasy wyższej, lecz tylko plebejkkie disco polo.

Podsumowując te dwa materiały dziennikarskie, można powiedzieć, że nie chodzi o osiągnięcie sukcesu, tak cenione w neoliberalizmie, ale o osiągnięcie sukcesu zgodnego z wyobrażeniem "Gazety Wyborczej” (dziennikarzy w niej pracujących). Nie liczy się przedsiębiorczość, ale

31 M. Borys, s. 216-217.

32 https://bialystok.wyborcza.pl/bialystok/7,35241,25698359,w-michalowie-ma-powstac-pierw-

sza-w-polsce-klasa-o-profilu-discopolowym.html [dostęp: I2 czerwca 2020]. 
przedsiębiorczość nakierowana na promowanie klasowo ukształtowanego gustu klasy wyższej. Neoliberalne reguły ekonomiczne, które są przedstawiane jako niezależne od ideologii, czysto ekonomiczne, gdy są realizowane przez kogoś z innym gustem, stają się już problemem, co tylko pokazuje, jak bardzo są ideologiczne i klasowe. Reguły okazują się nie dla wszystkich. Jeśli wolny rynek zaczyna coś regulować, a nie jest to zgodne z określonym gustem, wtedy, jak Z. Mikołejko, należy postulować ograniczenie wolności. Jego przykład pokazuje, jak bardzo niektórzy intelektualiści są strażnikami neoliberalnej hegemonii ${ }^{33}$, a dokładniej mówiąc, jego hegemonii wyobrażeń podsuwanych innym jako rzeczywistość tego, jak działa świat. Rację ma zatem M. Borys, pisząc:

Disco polo, zarówno jako prosta muzyka, jak i zestaw praktyk kulturowych z nią związanych, nie wpisało się w pożądany kanon wartości i zachowań, które miały cechować nowe liberalne społeczeństwo. Wypełniało kapitalistyczny scenariusz sukcesu, ale nie taki, jak napisały elity decydujące o kształcie transformacji. Równocześnie disco polo było nie w smak inteligencji, która upatrywała w nim znaku końca elitarnej polskiej kultury34.

\section{Czego nie rozumieją intelektualne elity?}

Dlaczego zatem tylko disco polo jest krytykowane, jeśli wcale nie jest gorsze od innych „złych”? Czy naprawdę zasługuje ono na to, żeby wartościować je aż tak negatywnie na tle innych zjawisk i fenomenów w świecie popkulturowych mediów? Jakie zatem przekonania regulują stosunek do disco polo? Dlaczego to ono wzbudza taką nienawiść?

Trudno nie zgodzić się z M. Borys, że:

Emocjonalna debata wokół filmu Bochniaka [Disco polo - przyp. M.R.] udowodniła, że etykieta "disco polo” jest zawsze czymś więcej niż tylko nazwą gatunku muzycznego. $Z$ jednej strony działa jak narzędzie demaskujące - jeśli go słuchasz, oznacza to najpewniej, że masz „zły gust”. Z drugiej strony „disco polo” ma moc niemal tożsamościową, nie można wobec niego pozostać obojętnym. Inteligenckie, cenzorskie niemal diagnozy o tym, że disco polo to „szmira”, która nie zasługuje na uwagę, nie są więc jedynie niewinną deklaracją gustu, ale mają za zadanie podtrzymać uznaną za obowiązującą i niepodważalną hierarchię smaku. Krytyczne głosy wobec filmu

33 Szerzej patrz: M. Wróblewski, dz. cyt., s. I 4-200.

34 M. Borys, dz.cyt., s. 97. 
Macieja Bochniaka wzmocniły inteligencką wizję kultury, która każdy rodzaj „zajmowania się” discopolową twórczością uznaje za podejrzany - nieważne, czy jest to zabawa przy chodnikowych dźwiękach, kinowa opowieść, czy może publicystyczna debata. Disco polo budzi szczególnego rodzaju obawę, dlatego elity pragną zawsze zaznaczyć wobec niego swoją pozycję i ustawić siebie jako „dyspozytora” gustu. Aby być inteligentem w Polsce, nie tylko nie można disco polo słuchać, ale za każdym razem, gdy temat ten pojawi się w debacie, należy zadeklarować swoją niechęć do tej muzyki35.

Stosunek do disco polo to wyznacznik klasowości, przynależności do tych „lepszych”, którymi jesteśmy, lub/i do których aspirujemy, albowiem gust, w tym muzyczny, to najlepszy znak rozpoznawczy tego, kim jesteśmy i skąd pochodzimy, za kogo chcemy uchodzić w towarzystwie ${ }^{36}$. Ma rację M. Borys, mówiąc, iż „disco polo wciąż można traktować jako papierek lakmusowy nastrojów społecznych i zawsze jest ekspresją społecznego konfliktu. Nigdy nie jest neutralne, wręcz przeciwnie - wywołuje skrajne emocje: kocha się je lub nienawidzi" ${ }^{37}$. W innym miejscu autorka trafnie odnotowuje, iż:

recepcja disco polo rezonuje dwie ważne współczesne debaty i rzuca na nie nowe światło. Jedna z nich dotyczy wpływu transformacyjnych przemian na obecny kształt społeczeństwa, nostalgicznego „powrotu do najntisów”, nowych odczytań rodzących się wtedy praktyk kulturowo-ekonomicznych Polaków. W tym kontekście discopolowa historia to trudna część transformacji - sukces, który jednak nie spełniał „zachodnich standardów”, do jakich miało równać polskie społeczeństwo. Discopolowiec - niezręcznie swojkki, niedoskonały, obnażający pułapkę imitacyjnego charakteru przemian - nie pasował do wizji tego, w jaki sposób mieli wyglądać świeżo upieczeni kapitalistyczni Polacy33.

Disco polo jest zasobem kontrhegemonicznym, nie tylko w warstwie inteligenckiego gustu estetycznego i jej wyobrażenia o rozrywce, ale także w warstwie deklarowanych konserwatywnych wartości (Polska, rodzina, lokalność, przywiązanie do tradycji i katolicyzmu). Uniemożliwia on inteligencji zbudowanie wyobrażenia o nas samych (i samej sobie), w kategoriach społeczeństwa nowoczesnego, o Polakach jako Europejczykach; wyobrażenia, w którym znaki zmitologizowanej „polskości-swojskości” muszą zostać wymazane,

35 Tamże, s. 250.

36 P. Bourdieu, Dystynkcja: spoteczna krytyka wtadzy sadzenia, Warszawa, 2005.

37 M. Borys, dz. cyt., s. 254.

38 Tamże, s. 257-258. 
i stworzone na wzór zachodni. Z tego względu, że nie pasuje ono do wyobrażenia elit, musi zostać albo usunięte z medialnego pola widzenia („niech wraca do domu”, mówił R. Leszczyński), albo jeśli już istnieje, musi być publicznie batożone przy medialnym pręgierzu. Moim zdaniem ci, którzy to robią, są kierowani kompleksem i wstydem, że są z tego samego narodu co słuchacze tego „kiczu”. Trzeba ich jak najszybciej „przerobić” na naszą wizerunkową modłę, bo tylko tacy możemy być częścią świata, do którego aspirujemy. Tak jak część programów telewizyjnych jest modernizacyjnym wykładem wartości neoliberalnych i mających na celu dostosowanie określonych ludzi z klasy średniej do swoich wyobrażeń ${ }^{39}$, tak przedwcześnie ogłoszony pogrzeb disco polo pokazuje, że akurat ono skutecznie się temu dostosowaniu opiera. Co więcej, fani disco polo jak „typowi Janusze”, o których pisałem w innym miejscu ${ }^{4}$, są sobą, nikogo nie udają, są wolnymi ludźmi, a nie więźniami społecznego panopticonu niemającymi ochoty aspirować do pozycji kogoś, kim nie są. I są w dużej mierze szczęśliwi w swoim zadowoleniu. Ten brak „ambicji” oraz „szczęście prostaczka” irytuje intelektualne elity chyba najbardziej (pewnie również dlatego, że przekroczenie progu krytycznego refleksji nigdy nie jest bezbolesne i nie ma już prostego powrotu do postawy zaangażowanej w świat). Innymi słowy, by użyć metaforyki Zygmunta Baumana, stoją w miejscu i nie chcą biec, „rozwijać się”, czyli kulturowo awansować. I to wywołuje gniew elit, bo ktoś podważa istotę nowoczesności. Jak zauważa socjolog:

Życie w społeczeństwie płynnej nowoczesności nie może stać w miejscu. Musi się modernizować (czytaj: pozbywać się codziennie cech i atrybutów, które przekroczyły swoją datę ważności, oraz dekomponować/porzucać aktualnie tworzone/klecone tożsamości) - w przeciwnym razie zmarnieje. Życie w społeczeństwie płynnej nowoczesności, ponaglane przez widmo dezaktualizacji, toczy się wartko naprzód. Nie trzeba go już kusić opowieściami o cudach wieńczących dzieło modernizacji. Teraz trzeba biec ile sił w nogach, aby pozostać na tym samym miejscu, z dala od pojemników na śmieci, do którego trafią niechybnie wszyscy maruderzy ${ }^{41}$.

Zamiast kisić kim chi, uczyć się języków czy grać w squash, piją piwo i jedzą karkówkę z grilla na działce, i są z tego powodu szczęśliwi. I to ich szczęście

39 M. Rydlewski, Scenariusze... ; Zob. także: Kultura upokarzania stabszych. Z dr. Michatem Rydlewskim rozmawia Tomasz Markiewka, „Nowy Obywatel” 2020, nr 32, s. 48-56.

40 M. Rydlewski, $Z$ czego się śmiejecie? Sami z siebie się śmiejecie! Internetowy fenomen Polaków-cebulaków: od szowinizmu anty-wiejskiego do kulturowej autoterapii, [w:] Media w środowisku cyfrowym, red. K. Konarska, P. Urbaniak, Wrocław 2020, s. 201-215.

4I Z. Bauman, Ptynne życie, Kraków 2007, s. 8. 
jest powodem nienawiści wynikającym z zazdrości, gdyż w realnym kapitalizmie do szczęścia trzeba dążyć z językiem na brodzie, a nie je osiągać i spoczywać na laurach. Nie są im potrzebne żadne kursy mindfullness, żeby cieszyć się smakiem zwykłego piwa z Biedronki.

\section{Patrz na funkcję (społeczną)! Disco polo jako (potrzebny) kicz}

Od początku profesjonalnej refleksji nad kiczem był on określany „sztuką szczęścia” ${ }^{2}$. Kicz, ta „zła sztuka” ma dostarczać przyjemności, tzw. „czystej przyjemności" nieuwarunkowanej wyrafinowaną wiedzą na temat sztuki, intertekstualnych odniesień danego dzieła, słowem, niewymagającej dużej wiedzy oraz nieangażującej w odpowiednio wysokim stopniu intelektu, myślenia, refleksji. Warto postawić wprost pytanie, co w tym ostatecznie złego? Moim zdaniem nic. Tylko z wyżyn akademickiego dyskursu (czego przykładem Z. Mikołejko), inteligenckiego poziomu (dziennikarze) będzie budziło politowanie, a nawet lekko skrywaną pogardę. „Moje szczęście jest lepsze od Twojego szczęścia”, zdają się mówić elity, bo oparte na wiedzy i myśleniu, a nie na nierefleksyjnym cieszeniu się banałem, tandetą, szmirą. Z. Mikołejko zdaje się sądzić, że powinniśmy wychowywać lud poprzez zlikwidowanie w telewizji disco polo i umieszczenie w programie „wyrafinowanego filmu bądź teatru”.

$\mathrm{Z}$ punktu widzenia nauk o kulturze banałem jest powiedzieć, że różne klasy społeczne, grupy społeczne, subkultury, środowiska, mają odmienne, mniej lub bardziej płynne brzegowo gusta estetyczne. Są one ukształtowane, przyjmując neomarksistowski punkt widzenia, przez konkretne uwarunkowania ekonomiczne, np. tryb i charakter pracy przekładający się z kolei na zarobki, poziom zmęczenia oraz ilość czasu wolnego. Wychodzę z założenia, że gust, czyli to, co nam się podoba, jest ukształtowany kulturowo, a zatem żeby go zrozumieć, trzeba umieć zrekonstruować kulturę, w której i poprzez którą, ona się wyraża. Jest on związany z życiem codziennym, potocznym funkcjonowaniem danych podmiotów i jednocześnie słuchaczy danej muzyki czy widzów danych programów telewizyjnych.

Nie są to myśli odkrywcze, o czym świadczy namysł nad tzw. literaturą brukową, w tym szczególnie dobrze rozpoznawalnymi Harlequinami. Kłopot w tym, że nawet kiedy dostrzega się kulturowe uwarunkowanie gustu, to nie czyni się z tego faktu żadnego użytku poznawczego, co prawdopodobnie wynika z tego, iż owe dostrzeżenie to taki sympatyczny dodatek uwzględniany w tekście naukowym na zasadzie rozrywkowej. Przykładowo Iwona 
Pięta, omawiając kicz w literaturze, przywołując myśl Abrahama Molesa, iż wysiłek jakiego wymaga, nie przekracza zalecanej nowocześnie gimnastyki umysłowej, jest zdrowy, stwierdza:

W tym miejscu można by się uśmiechnąć i stwierdzić: no tak, mało ambitna literatura dla mało ambitnego czytelnika, ale z drugiej strony, (I) czemu odmawiać racji bytu czemuś, co niesie ze sobą tyle dobrego, pozwalając człowiekowi zejść z wyżyn wysoko stechnicyzowanego i cywilizowanego świata w nieco inną sferę, [...] (3) biorąc pod uwagę tempo i ilość w jakich owa drugorzędna produkcja literacka znika z księgarskich pólek, zapotrzebowanie na nią jest bardzo duże, a powiedzmy sobie uczciwie - całkiem poważni i poważnie wykształceni ludzie też często, choć rzadko to ujawniają, sięgają po książki, nad którymi, użyję popularnego stwierdzenia, nie trzeba myśleć i można sobie pozwolić na chwilę odprężenia i brak profesjonalizmu w dokonywaniu oceny wartości i interpretacji „dzieła literackiego". A trochę poważniej $[\ldots]{ }^{\prime \prime}$.

I dalej w artykule następuje to „trochę poważniej” mówiące o gruncie krytyki literackiej. Trzeba jednak, tam gdzie I. Pięta jest niepoważna, potraktować to, co mówi, jak najbardziej poważnie, opuszczając tym samym "grunt krytyki literackiej”, a kierując się w stronę praktyk kulturowych osadzonych na gruncie danej grupy czy klasy społecznej.

Wyobraźmy sobie codzienne życie stereotypowej czytelniczki ${ }^{44}$, która obcuje z tą literaturą w sposób naiwno-realistyczny, a nie ironiczno-relaksacyjny, charakterystyczny raczej dla osób z wyższym kapitałem kulturowym, które będą czytały tego typu literaturę po chwilach dużego intelektualnego zmęczenia. To raczej kobieta z klasy robotniczej, pracująca fizycznie, która nie skończyła renomowanego uniwersytetu, zajmująca się po pracy dziećmi i domem. Po swoim ośmiogodzinnym dniu pracy musi zająć się przygotowaniem obiadu (zakupy, gotowanie), sprzątaniem, odrobieniem lekcji z dziećmi, praniem, prasowaniem. Czy po takim dniu Z. Mikołejko oczekuje, że ta kobieta zagłębi się w lekturę Martina Heideggera lub zacznie analizować filmy Andrieja Tarkowskiego? Dlaczego w ogóle ma takie oczekiwania? Co zrobił, żeby oczekiwać od niej, by użyć jego własnego sformułowania, „awansu kulturowego”? Bo myśli, że wszyscy ludzie w tym

43 I. Pięta, Czy kicz jest nadal kiczem - kilka uwag na temat definicji w literaturze polskiej końca XX wieku, [w:] Kicz, tandeta, jarmarczność w kulturze masowej XX wieku, red. L. Rożek, Częstochowa 2000, s. 87.

44 Taki zabieg ma na celu tylko i wyłącznie zbudowanie pewnego „obrazu poglądowego”, ażeby uwydatnić to, o czym mówię. Można by oczywiście przeprowadzić badania nad czytelnictwem tzw. literatury brukowej, uważam, że potwierdziłyby one w dużej mierze klasowy obraz. 
kraju mają takie życie jak on, co jest po prostu empirycznie błędne, wszak społeczeństwo to nie zbiór bezklasowych jednostek. Jeśli warszawski filozof ma oczekiwania względem tej kobiety, to niech jej pomoże, np. odrabiając z dziećmi lekcje, zabierze do muzeum czy teatru i nauczy ich odbioru sztuki wysokiej. Z punktu widzenia tej kobiety racjonalnym (w sensie kulturoznawczym, a nie filozoficznym) jest obejrzenie paradokumentu (również uchodzącego za kicz), który, ze względu na swój scenariusz, daje się „oglądać” ${ }^{4}$ i wykonywać inne czynności, np. prasowanie. Inteligent, jak Z. Mikołejko, nie wnika w takie „szczegóły”: „jak człowiek głupi, to i głupich rzeczy słucha”, chciałoby się powiedzieć. Moim zdaniem, nic tak nie kompromituje intelektualisty, w tym humanisty, jak nieumiejętność zobaczenia kontekstu społecznego, bez którego popada się w tandetne psychologizowanie podszyte neoliberalnym hiperindywdualizmem: każdy ma swój gust i jest za niego odpowiedzialny.

\section{Im więcej upokarzania, tym więcej gniewu, czyli o potrzebie autoterapii Polaków}

Dzisiejszy renesans disco polo jako produktu medialno-rozrywkowego, który w pewnym momencie zazębił się z wcześniejszą wojną kulturową oraz późniejszą wojną polityczną, jest przykładem, jeśli uznać za trafne refleksje Andrzej Ledera ${ }^{46}$ czy Jana Sowy ${ }^{47}$ względem nieprzepracowanej traumy pańszczyzny i wstydu z wiejskiego pochodzenia wypartego do nieświadomości zbiorowej, klasowego odwetu przejawiającego się na gruncie kultury w rozumieniu szkoły z Birmingham jako terenie ideologicznej walki o władzę, w tym władzę definiowania, co jest dobre, a co złe. To odwet na intelektualnych elitach pogardzających tymi na dole drabiny społecznej, ciemnogrodem, głupszymi wieśniakami, niewykształconą masą kolebiącą się w rytm disco polo, która nagle przestała się wstydzić swojego gustu, odrzuciła narzucany im wstyd, tym samym wymykając się spod kontroli estetyczno-ideologicznej na klasowej granicy. Paszport, wydawany przez

45 Paradokumenty są w zasadzie bardziej do słuchania, niż oglądania, ewentualnie „zerkania”, co widać w narracji typu: „Bożena wychodzi z bloku, gdzie spotyka Stefana, który niesie ze sobą zakupy”. To jest narracja obrazowa, tak uformowana, żeby można było wykonywać w tym czasie inne czynności i nie tracić nic z akcji danego odcinka.

46 Leder, Prześniona rewolucja. Ćwiczenia z logiki historycznej, Warszawa 2014.

47 J. Sowa, Fantomowe ciato króla. Peryferyjne zmagania z nowoczesnąformą, Kraków 2011 . Abstrahując od dyskusji wokół tej książki, tego, na ile materiał historyczny pozawala na interpretację autora, to traktuję ją, analogicznie jak książkę A. Ledera, jako zasób ciekawych i świeżych metafor służących opisowi polskiego społeczeństwa. Podobnie zresztą traktuję pojęcia „elit” oraz „ludu” - są one realnie funkcjonującymi wyobrażeniami, które ujawniły się czy zostały odświeżone po katastrofie smoleńskiej, albowiem wtedy zaczęto mówić o „ludzie smoleńskim”. 
odpowiednie władze, czyli elity intelektualne, nie jest już potrzebny, bo ta granica już nie istnieje (co z pewnością ma swoje różne konsekwencje).

Wspomniany odwet, nazwijmy go „odwetem kulturalnym”, wynika w dużej mierze z tego, co Andrzej Szahaj określił mianem „pamięci upokorzenia”, czyli trwającego lata poczucia upokorzenia pewnej grupy ludzi po okresie transformacji, którzy przechodząc ekonomiczną i symboliczną jak najbardziej przeżywaną traumę, otrzymali dodatkowy policzek w twarz mówiący, iż są bezwartościowi, bo nie potrafią być nowocześni, słowem, zabrano im nie tylko pracę, ale również honor i godnośćc $4^{8}$. Jak celnie zauważył A. Szahaj w innym miejscu, pisząc o posttransformacyjnej traumie, z którą musiała zmagać się część polskiego społeczeństwa, jej ofiary wcale nie cierpiały na jakiś znaczący deficyt kompetencji społecznych, nie były nadmiernie roszczeniowe ani nie reprezentowały tak modnej figury homo sovieticus ${ }^{49}$. Wręcz przeciwnie, twierdzi toruński filozof: „Często okazywali się de facto bardziej przedsiębiorczy niż najbardziej przedsiębiorczy biznesmeni, potwierdzając w ten sposób hipotezę wybitnego ekonomisty brytyjskiego koreańskiego pochodzenia Ha-Joon Changa, że ludzie ubodzy są często bardziej przedsiębiorczy niż ludzie bogaci, albowiem muszą przeżyć w niesprzyjających warunkach i bez niczyjej pomocy"so, czego disco polo jest tego znakomitym przykładem, gdyż ta muzyka powstała w oddolny, nieprofesjonalny sposób, gromadząc różne zasoby (ekonomiczne, symboliczne, materialne itd.) oraz wyrażając gust sporej części tych ludzi, którzy byli w dużej mierze stygmatyzowani. To oni osiągnęli sukces $w$ iście amerykański sposób, przejmując nawet pewne amerykańskie nawyki sukcesu, o czym wspomina Sławomir Świerzyński w filmie pt. Bara, Bara, przy czym nie wyćwiczyli amerykańskich twarzy, by odwołać się do motta mojego tekstu, pozostali swojscy.

Dzisiaj to elity się rozgniewały, gdyż straciły władzę, zostały symbolicznie upokorzone, co swoją drogą pokazuje, że mają problem z demokracją, czego przykładem jest wypowiedźZ Z. Mikołejki. Częśćludzi, w tym słuchacze disco polo, nie chcą grać w grę, której reguły ustaliły elity i wobec których są one funkcjonalne. Teraz to krytyk muzyczny, jak Bartosz Chaciński, schodzi do "podziemia”, gdyż sama dyskusja o disco polo rani jego estetykę władzy, czyli stracenie kontroli nad odczuwaniem wstydu z powodu tego, kim się jest (a jest się tym, czego się słucha), powoduje wzrost agresji elit względem

48 A. Szahaj, Pamięć upokorzenia, [w:] Kapitalizm wyczerpania?, Warszawa 2019, s. I27; T.S. Markiewka, dz.cyt., s. IIo-III.

49 A. Szahaj, Neoliberalizm, turbokapitalizm, kryzys, Warszawa 2017, s. 122.

50 Tamże, s. 122 .

5I M. Borys, dz. cyt., s. 250. 
disco polo, czego przykładem była wypowiedź H. Lis. Z drugiej strony, uwolnienie części ludzi od wspomnianego wstydu (część z nich zapewne w ogóle go nie odczuwała), uznanie muzyki disco polo za pełnoprawny gatunek muzyczny (i jego promocja w telewizji publicznej), którego słucha duża część Polaków, mają swoją zaletę, gdyż dzięki temu słuchacze nie czują się upokarzani, pogardzani oraz stygmatyzowani za swój gust. Spora część słuchaczy disco polo przestaje się po prostu wstydzić tego, kim jest, i jawnie pokazuje swoje autentyczne Ja, które to - niepasujące do wizji neoliberalnego i nowoczesnego społeczeństwa polskiego - musiało być ukrywane na prowincji.

To bycie sobą - autentyczność, ten fetysz kultury współczesnej - był do tej pory zarezerwowany jedynie dla klasy dominującej, w tym jej części złożonej z tzw. klasy szampańskiej (celebrytów, dziennikarzy, aktorów, piosenkarzy itd.), zaś klasie podporządkowanej nie wolno było być sobą.

Weźmy przykład związany z antybohaterką mojej książki ${ }^{\text {s2 }}$, który dobrze pokazuje, co mam na myśli. Na zarzuty o jawne upokarzanie uczestników w Kuchennych rewolucjach Magda Gessler odpowiada, że taka po prostu jest, chce być zawsze sobą, co przejawia się m.in. poprzez mówienie prawdy. Jest bezkompromisowa, jak informuje nas czołówka każdego odcinka Kuchennych rewolucji. Fakt, że wypowiadanie tej prawdy jest zabarwione wręcz sadystyczną szczerością i publicznym ujawnianiem rodzinnych konfliktów, sekretów, a nawet nałogów, zupełnie jej nie zajmuje, a może to prowadzić do nieprzewidzianych i niepożądanych konsekwencji w sensie psychicznym. Zdaniem wielu fanów M. Gessler, takie zachowanie zasługuje na szacunek i uznanie, gdyż każde inne jest fałszywe, w domyśle nieautentyczne. Dlaczego mam ograniczać swoją ekspresję? Bo to może skrzywdzić innych? Trudno, moja wolność i autentyczność ponad wszystko! Nawiasem mówiąc, kiedyś w kulturze europejskiej znakiem dobrego wychowania było panowanie nad sobą i wcale nie czyniło to człowieka nieautentycznym.

W innym miejscu szerzej pisałem, że w sporej części programów telewizyjnych dotyczących przemian / metamorfoz (makeover shows) odbywa się podszyty upokorzeniem proces modernizacji polskiego społeczeństwa, mentalnego dostosowania go do wartości neoliberalnych, które stają się kodek-

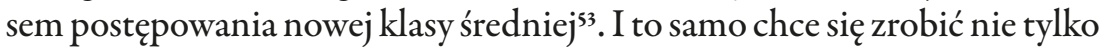
z uczestnikami programów telewizyjnych, ale z tzw. zwykłymi ludźmi, np. słuchaczami disco polo. Pojawia się jednak fundamentalne pytanie. Dlaczego M. Gessler ma prawo być sobą, a oni nie? Kto ma to wyznaczać? Jeśli M. Gessler nie wstydzi się tego, jaka jest, to dlaczego mają wstydzić się inni? Dlaczego

\footnotetext{
52 M. Rydlewski, Scenariusze..., s. I3I-137.

53 Kultura upokarzania..., s. 48-56.
} 
jednym wolno coś, czego nie wolno innym? Otóż dlatego, że nie wszyscy są równi, jedni są gorsi i należy ich albo zmienić, albo usunąć z pola widzenia.

W perspektywie studiów kulturowych łączących ze sobą kulturę, ideologię oraz pole polityki należy zauważyć, iż obecna partia rządząca zrozumiała i umiejętnie zagospodarowała ich upokorzenie i gniew, wykluczenie w reprezentacji swojego gustu w publicznej przecież telewizji, analogicznie do tego, jak wcześniej miało to miejsce z religijnością ludową, która świetnie odnalazła się w stworzonym na ich potrzeby Licheniu oraz Radiu Maryja. Ona również była i jest traktowana jako kicz, a przecież trzeba ją zobaczyć w całym kontekście społecznych wyobrażeń (jest gorsza, bo nie jest z naszych, inteligenckich wyobrażeń), co pokazuje, że nic nie jest kiczem samym w sobie, lecz jest zawsze przez kogoś wyznaczane, narzucane, uwewnętrzniane, aby kontrolować granice klasowe. Co więcej, partia rządząca potrafiła wykorzystać symboliczno-konsumpcyjne wykluczenie części młodych prekariuszy z niższym kapitałem kulturowym, dając im tożsamościową i wspólnotową narrację w postaci Żołnierzy Wyklętych (tym z wyższym kapitałem kulturowym neoliberalizm podsuwa m.in. coaching, samorozwój i mindfullnes, czyli projekty „ulepszania siebie” w trybie indywidualistycznym ${ }^{54}$ ).

Wspomniane przykłady zasługiwałyby na odrębny tekst, ale widać, że tak jak w przypadku disco polo walka o władzę toczy się na polu kultury jako obszarze pomiędzy klasą dominującą a klasą podporządkowaną; że ta walka splata ze sobą wielu aktorów, zarządzając nimi poprzez emocje. Doprawdy trudno inaczej wyjaśnić, dlaczego ten właśnie fenomen muzyczny budzi tak skrajne emocje.

Może już czas przyznać, że tacy po prostu jesteśmy i że nie ma w tym nic złego? Disco polo i jego losy mogą stać się (na naszych oczach stają się?) kulturową autoterapią sporej części Polaków wyzbywających się wstydu z wiejskiego pochodzenia i narzucanej od dekad przez elity kontroli siebie samego (uwewnętrznianej samoobserwacji), analogicznie jak ma to miejsce w przypadku narracji o „typowych Januszach”ss. Pewne grupy polskiego społeczeństwa nie poddały nie nadzorowi w społecznym panoptykonie, w tym sensie słuchacze disco polo nie dali się ani zmienić, tj. stworzyć na

54 M. Rydlewski, Fikcjonariusze fatszywejideologii. Antropologia coachingu,[w:] Antropologia, media, komunikacja, red. M. Czapiga, M. Rydlewski, Wrocław 2019, s. 39-71. Stosując kursywę z zapisie niższego oraz wyższego kapitału, chcę podkreślić swój ambiwalentny stosunek do tych pojęć, gdyż zawiera się w nich ukryte wartościowanie (niskie - złe, wysokie - dobre). Używając ich, nie mam na celu poniżenia jego posiadaczy, traktowania ich jako gorszych, gdyż wtedy zrobiłbym to, co robią opisywani przeze mnie przedstawiciele elit. Lepiej byłoby chyba mówić po prostu o różnych/odmiennych/innych kapitałach kulturowych. W języku nauki także może tkwić postawa strukturalnej wyższości, choć używający go badacz może mieć jak najlepsze intencje. Za tę uwagę dziękuję Profesorowi Aleksandrowi Woźnemu.

55 M. Rydlewski, $Z$ czego sięśmiejecie... 
wzór nowoczesnego odbiorcy kultury, podobnie jak ma to miejsce w programie dokonującym zmiany z wieśniaczki w damę, ani nie dali się zmarginalizować. Ponadto, przykład zespołu Weekend pokazuje, że czego zespoły discopolowe by nie zrobiły w sensie swojej wizerunkowej przemiany (upodobniły się do popu), to i tak nie zadowolą elit, bo być może nawet nie chodzi o dostosowanie, ale o to, żeby zawsze istniał ktoś do dostosowania i kim można w tym procesie ujarzmiania bezkarnie pogardzać.

\section{Bibliografia}

\section{Opracowania}

Bauman Z., Ptynne życie, Kraków 2007.

Borys M., Polski bajer. Disco polo i lata 9o., Warszawa 2019.

Dabert K., Krótka historia disco polo, „Zeszyty Etnologii Wrocławskiej” 2012, nr I.

Dunn E., Prywatyzując Polskę: o bobofrutach, wielkim biznesie i restrukturyzacji pracy, przeł. P. Sadura, Warszawa 2017.

Filar W., Fenomen muzyki disco polo w kontekście polskiej kultury popularnej lat go., „Kultura Popularna" 2014, $\mathrm{nr}$ I.

Kloch Z., Odmiany dyskursu. Semiotyka życia publicznego w Polsce po 1989 roku, Wrocław 2006.

Kultura i hegemonia. Antologia tekstów szkoty z Birmingham, red. M. Wróblewski, Toruń 2012.

Kultura upokarzania stabszych. $Z$ dr. Michatem Rydlewskim rozmawia Tomasz Markiewka, „Nowy Obywatel” 2020, nr 32.

Leder A., Prześniona rewolucja. Ćwiczenia z logiki historycznej, Warszawa 2014.

Leszczyński R., Pogrzeb disco polo, „Gazeta Wyborcza”, 6 II 1997.

Małanicz-Przybylska M., Disco polo from the Podhale region: the cultural Power game, „Ethnologia Polona" 2018, vol. 39 .

Markiewka T.S., Gniew, Wołowiec 2020.

Moles A., Kicz czyli sztuka szczęścia: studium z psychologii kiczu, Warszawa 1978.

Napiórkowski M., Trudność muzyki poważnej jako wspótczesna próba inicjacyjna, „Sztuka i Filozofia” 2012, nr 40.

Pięta I., Czy kicz jest nadal kiczem - kilka uwag na temat definicji w literaturze polskiej końca XX wieku, [w:] Kicz, tandeta, jarmarczność w kulturze masowej XX wieku, pod red. L. Rożek, Częstochowa 2000.

Rydlewski M., Fikcjonariusze fatszywej ideologii. Antropologia coachingu, [w:] Antropologia, media, komunikacja, red. M. Czapiga, M. Rydlewski, Wrocław 2019.

Rydlewski M., Nowi-starzy obcy w realnym kapitalizmie. Mieszkańcy polskiej wsi jako ofiary swojego stylu życia (na przyktadzie wybranych obrazów medialnych), [w:] Retro sentyment, retro moda, retro nadzieje, red. M. Czapiga-Klag, M. Rydlewski, Wrocław 2020.

Rydlewski M., Scenariusze kultury upokarzania. Studium z antropologii mediów, Wrocław 2019.

Rydlewski M., Z czego się śmiejecie? Sami z siebie się śmiejecie! Internetowy fenomen Polaków-cebulaków: od szowinizmu anty-wiejskiego do kulturowej autoterapii, [w:] Media wśrodowisku cyfrowym, red. K. Konarska, P. Urbaniak, Wrocław 2020.

Samborski T., Zdtawiliście disco polo, „Gazeta Wyborcza”, 6 II 1997.

Sowa J., Fantomowe ciato króla. Peryferyjne zmagania z nowoczesna formą, Kraków 201 I.

Szahaj A., Blaski i cienie merytokracji, [w:] A. Szahaj, Neoliberalizm, turbokapitalizm, kryzys, Warszawa 2017. 
MICHAt RYDLEWSKI Disco polo jako zasób kontrhegemoniczny wobec metamorficznych praktyk...

Szahaj A., Pamięć upokorzenia, [w:] Kapitalizm wyczerpania?, Warszawa 2019.

Szarecki A., Kapitalizm somatyczny: ciato i wtadza w kulturze korporacyjnej, Warszawa 2017.

Woźniak Z., Fenomen disco polo i jego miejsce w polskiej kulturze masowej lat dziewięćdziesiatych, „Etnografia Polska” 1998 , t. 42.

Wróblewski M., Hegemonia i wtadza. Filozofia polityczna Antonio Gramsciego i jej wspótczesne kontynuacje, Toruń 2016.

Wróblewski M., Wierni jako zasób kontrhegemoniczny: spór o krzyż w kontekście teorii hegemonii, „Kultura Popularna” 2014, nr I.

\section{Strony internetowe}

https://bialystok.wyborcza.pl/bialystok/7,35241,25698359,w-michalowie-ma-powstac-pierwsza-w-polsce-klasa-o-profilu-discopolowym.html

https://krakow.wyborcza.pl/krakow/7,44425,25906805,nietakt-czyli-filolog-czyta-grafomanow.html

https://kultura.onet.pl/wywiady-i-artykuly/prof-zbigniew-mikolejko-zycie-w-trzewiach-bestii-wywiad/m5 $\mathrm{fl}_{4} \mathrm{mt}$

https://niezalezna.pl/304237-skandaliczny-wpis-hanny-lis-w-sylwestrowy-wieczor-teraz-sie-tlumaczy-nie-mam-nic-do-disco-polo

https://weekend.gazeta.pl/weekend/r,I52121,20393461,kazde-miasto-ma-swoj-x-factor-moda-na-lokalne-wersje-talent.html

https://wyborcza.pl/7,75410,25697681,zenek-martyniuk-jak-to-sie-stalo-ze-

-czlowiek-idealnie-nijaki.html

Streszczenie: W artykule poddaję refleksji niechęć do gatunku muzyki disco polo. Ta niechęć jest widoczna w poglądach wielu członków elity intelektualnej polskiego społeczeństwa, którzy uważają tę muzykę za kicz. Stosunek do tej muzyki, słuchanej głównie przez mieszkańców wsi i małych miasteczek, jest wskaźnikiem gustu kulturowego, a zatem znakiem przynależności klasowej. Jeśli chcesz być lepszy, poniżaj słuchaczy disco polo. W artykule pokazuję, że słuchacze disco polo okazali się silnym zasobem antyhegemonicznym, który nie został dostosowany do gustów wyższej klasy. Dlatego należy nim gardzić, gdyż oparł się nowej władzy - estetyce.

Słowa klucze: disco polo, hegemonia kulturowa, neoliberalizm, kicz, Gazeta Wyborcza

Summary: The article discusses dislike for the music genre called disco polo. This reluctance is evident in the views of many members of the intellectual elite of the Polish society who consider this music kitsch. The attitude towards this music, listened to mainly by the inhabitants of villages and small towns, is an indicator of cultural taste, and thus a sign of class affiliation. If you want to be better, humiliate disco polo listeners. The article shows that disco polo listeners turned out to be a strong anti-hegemonic resource that has not been adapted to the tastes of the upper class. Therefore, it should be degraded, because it presents a new kind of power i.e. esthetic.

Keywords: disco polo, cultural hegemony, neoliberalism, daub, Gazeta Wyborcza 